\title{
現場型硫化物センサーを用いた硫化物の鉛直 分布の測定およびその分布の特徵 \\ ON-SITE MEASUREMENT OF VERTICAL DISTRIBUTION OF HYDROGEN SULFIDE USING MICRO SENSOR AND ITS CHARACTERISTICS
}

\author{
岡田知也 ${ }^{1} \cdot$ 吉田潤 $^{2} \cdot$ 古川恵太 ${ }^{1}$ \\ Tomonari OKADA, Jun YOSHIDA and Keita FURUKAWA \\ '正会員 博 (工学) 国土交通省国土技術政策総合研究所 沿岸海洋研究部海洋環境研究室 \\ （干238-0826 神奈川県横須賀市長瀬 $3-1-1$ ） \\ 2工修＼cjkstart国土交通省国土技術政策総合研究所 沿岸海洋研究部海洋環境研究室 \\ （干238-0826 神奈川県横須賀市長瀬3-1-1）
}

\begin{abstract}
We demonstrated applicability of a sensor, which can directly measure hydrogen sulfide $\left(\mathrm{H}_{2} \mathrm{~S}\right)$ concentration onsite, to monitoring for marine environment, and characteristics of vertical distribution of $\mathrm{H}_{2} \mathrm{~S}$ from the data obtained using the sensor. Observations were carried out in Tokyo bay in 2010. The data measured by the sensor correlated with the analyzed data of sampled water, but the former were less than half the latter. Therefore, we think that we should use the sensor for quality examinations at the present time. Regarding to the vertical distribution of $\mathrm{H}_{2} \mathrm{~S}$, the followings were shown. $\mathrm{H}_{2} \mathrm{~S}$ also existed in the bottom layer at the head of the bay. The layer was $2 \mathrm{~m}$ high and the concentration of $\mathrm{H}_{2} \mathrm{~S}$ was about one-tenth of the concentration in the deeply excavated site. And high concentration of $\mathrm{H}_{2} \mathrm{~S}$ existed in the bottom layer at Shibaura canal, which was only four meter deep.
\end{abstract}

Key Words: Hydrogen sulfide, Sulfide, Anoxic water, Deeply excavated site, $\mathrm{H}_{2} \mathrm{~S}$ micro sensor

\section{1.はじめに}

富栄養化した内湾において，青潮は象徵的な富 栄養化の負の影響イベントである。青潮は，規模 によっては，沿岸域の干潟や浅場の底生生物の大 量へい死を招く1)。それにもかかわらず，現状の環 境モニタリングにおいては，青潮の発生要因とな る貧酸素水塊（溶存酸素濃度）は測定されている ものの, 青潮の形成要因である肝心の硫化物濃度 や硫化水素濃度は殆ど測定されていない。そのた め，湾内において，硫化物がどの範囲に分布し，硫 化物量がどの程度存在しているのか，正確には把 握されていないのが実状である。このことが，青 潮の発生範囲および規模の的確な予測を困難なも のとしている.

この硫化物のデータ不足を解消するため, 著者 らは，吊り下げ式で容易に硫化物濃度を測定でき る現場型の溶存硫化水素測定器（H2S-100, AMT 社 製）の実海域での使用を試みた。本研究では，本 測器の実海域における環境モニタリングへの適用 性を検討すると共に, 硫化物がどの水域にどの様
な鉛直分布で存在しているのかを把握することを 目的として調查を行った。

\section{2. データ}

\section{（1）現地観測}

東京湾において, 湾奥の浚渫窪地 $(\mathrm{A}, \mathrm{E})$, 湾奥 部の平場（B， C, D ）, 東京港内（F）および芝浦運 河 (G) を調查地点とした（図-1)。調查は 2010 年 8 月 17 日， 27 日， 9 月 17 日の 3 回実施した。船上か ら溶存硫化水素測定器および多項目水質計（AAQRINKO，JFE アドバンテック社製）を用いて，硫化 水素 $\left(\mathrm{H}_{2} \mathrm{~S}\right)$ 濃度, 硫化物濃度, 溶存酸素（DO）濃 度, $\mathrm{pH}$, 酸化還元電位 (ORP), 水温, 塩分等を測 定した。

溶存硫化水素測定器は, 電極径が $25 \mu \mathrm{m}$ 以下のマ イクロセンサーを用いて, $\mathrm{H}_{2} \mathrm{~S}$ 分子の総量に関連し た電流を検出し, $\mathrm{H}_{2} \mathrm{~S}$ 濃度を測定する ${ }^{2)}$.

海水中の $\mathrm{H}_{2} \mathrm{~S}$ は, 海水中に溶けている硫酸イオン $\left(\mathrm{SO}_{4}{ }^{2-}\right)$ が嫌気状態において硫酸還元細菌による硫 


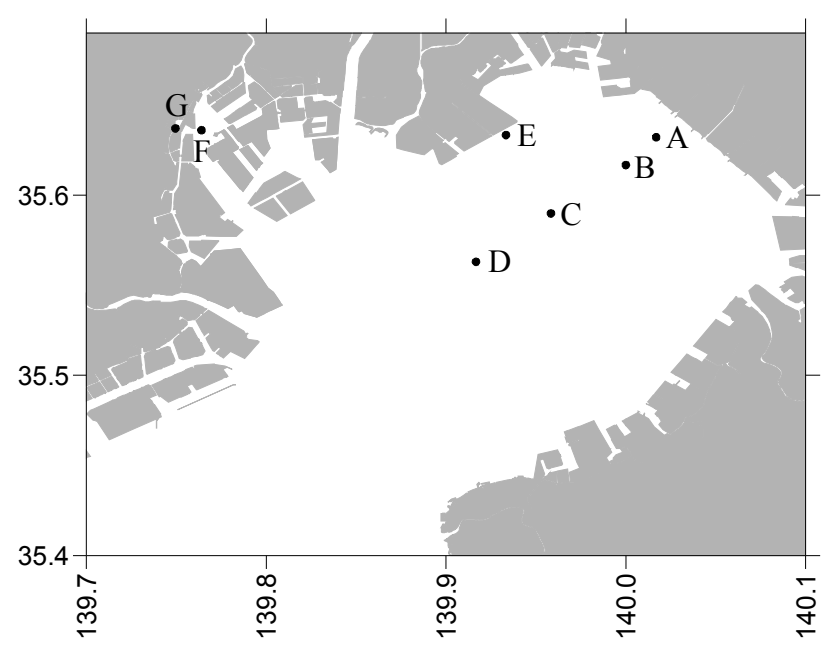

図-1 東京湾における観測地点図. AおよびEは浚渫窪 地内.

酸還元作用によって生成される， $\mathrm{H}_{2} \mathrm{~S}$ は $\mathrm{pH}$ に依存 して次式の平衡を示す ${ }^{1), 2)}$.

$$
\begin{array}{ll}
\mathrm{H}_{2} \mathrm{~S} \Leftrightarrow \mathrm{H}^{+}+\mathrm{HS}^{-} & \mathrm{pH}<8.5 \\
\mathrm{HS}^{-} \Leftrightarrow \mathrm{S}^{-}+\mathrm{H}^{+} & \mathrm{pH}>8.5
\end{array}
$$

ここでHS-は硫化水素イオンである。海水中では, $\mathrm{pH}$ の值から上式のみ考慮すればよく, 本研究での （全）硫化物濃度は, $\mathrm{H}_{2} \mathrm{~S}$ 濃度と $\mathrm{HS}^{-}$濃度の和を示す。

$\mathrm{H}_{2} \mathrm{~S}$ 濃度と $\mathrm{HS}$ - 濃度の平衡バランスは, 次式で与 えられ

$$
\frac{\left[\mathrm{H}_{2} \mathrm{~S}\right]}{\left[\mathrm{HS}^{-}\right]+\left[\mathrm{H}_{2} \mathrm{~S}\right]}=\frac{1}{10^{\mathrm{pH}-\mathrm{pK}^{\prime}}+1}
$$

ここで $\mathrm{pK}{ }^{\prime}$ は塩分 30 , 水温 $20^{\circ} \mathrm{C}$ の場合, 6.62 が与え られている3). 図-2 は両者の平衡バランスを示し たものである。このように， $\mathrm{H}_{2} \mathrm{~S}$ と $\mathrm{pH}$ が測定され れば，併せて硫化物濃度も求めることができる。

$\mathrm{H}_{2} \mathrm{~S}$ センサーの応答時間（t90\%）は $200 \mathrm{~ms}$ 以下で あり， $\mathrm{H}_{2} \mathrm{~S}$ センサーの応答速度は非常に早いが，硫 化物量の算定のためには上述の様に $\mathrm{pH}$ の值が重要 であるため, $\mathrm{pH}$ の安定を待つ必要がある.また，波 による船の動摇によってセンサー位置が数 $10 \mathrm{~cm}$ 程 度上下変動したりし，測定值が振動した。そこで, $\mathrm{H}_{2} \mathrm{~S}$ 濃度に関しては, pH が安定してから 1 分間以上 の連続測定（測定間隔：0.25 s) を行った。解析に おいては，その連続データの時間平均值を測定值 とした.

$\mathrm{H}_{2} \mathrm{~S}$ センサータイプは0.01-3 $\mathrm{mg} \mathrm{l}^{-1}$ と 0.5-50 $\mathrm{m} \mathrm{l}^{-1}$ の

2 種類あり, 測定層の濃度に合わせて選定した。

本測器の検証用として, 3 回の調查のうちで 9 サ ンプルの採水を行い, 硫化水素濃度および硫化物 濃度を分析した。バンドーン採水器を用いて採水 された水塊は, 船上にて遮光・保冷保管し, 分析室 においてガスクロマトグラフ法にて分析した.

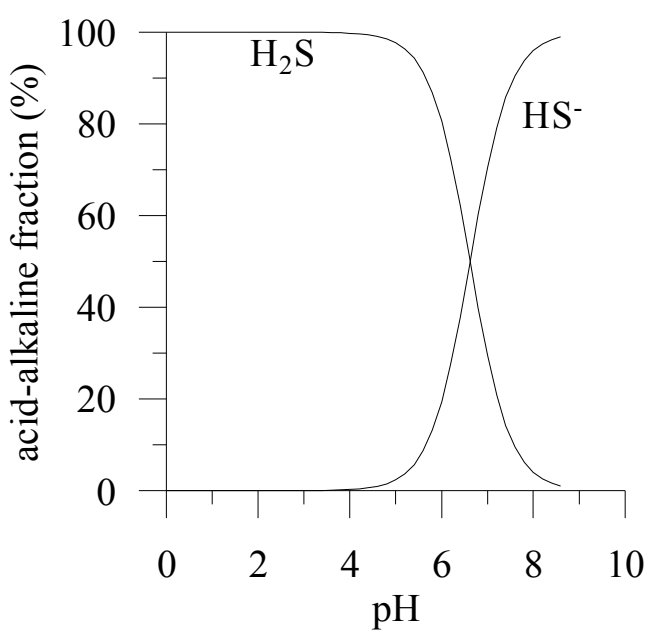

図-2 $\mathrm{pH}$ に対する $\mathrm{H}_{2} \mathrm{~S}$ と $\mathrm{HS}^{-}$の割合. 水温: $25^{\circ} \mathrm{C}$, 塩 分 : 30 .

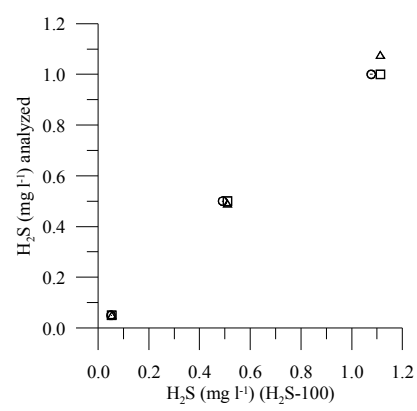

(a)

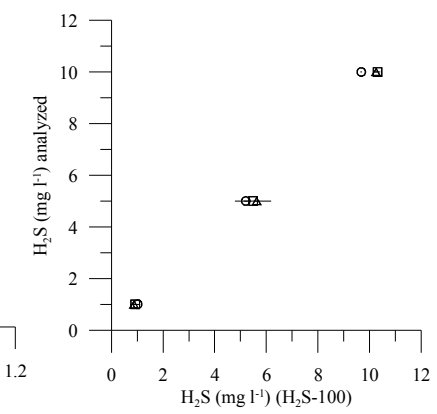

(b)
図-3 実験室における分析值とセンサー值の比較 (ス ターラー回転数 $(\mathrm{rpm}), \bigcirc:$ 無回転, $\square: 100$, $\triangle:$ 500). (a) センサータイプ0.01-3, (b) センサータ イプ0.5-50. 各プロット1分間以上連続測定の平均 值であり, 横バーは標準偏差を示す.

\section{（2）室内実験}

現場におけるセンサー值の誤差要因として, セ ンサー周りの水塊の擾乱が予測された. 実験室に おいて, ビーカ内に硫化物を含んだ浚渫窪地 $\mathrm{A} の$ 底層水を入れ，スターラーを用いて擾乱を発生さ せた状態で測定を行った。表層水および底層水の 採水は，2010年 10 月 13 日に実施した。底層水の $\mathrm{H}_{2} \mathrm{~S}$ 濃度はガスクロマトグラフ法で分析し, $11.0 \mathrm{mg} \mathrm{l}^{-1}$ だった。 その水塊を同地点の表層水（硫化物濃度 0 $\left.\mathrm{mg} \mathrm{l}^{-1}\right)$ を用いて， $0.05 ， 0.5,1.0,5.0,10.0 \mathrm{mg} \mathrm{l}^{-1}$ に 調整した。 スターラーの回転数は, 無回転, 100, 500 rpmとした.

\section{3. 結果}

\section{（1）室内実験結果}

分析值とセンサー值は, スターラー回転数 100 , $500 \mathrm{rpm}$ に対して，2つのセンサータイプ共に非常に 良く一致した（図-3）。時間変動の標準偏差は，図 


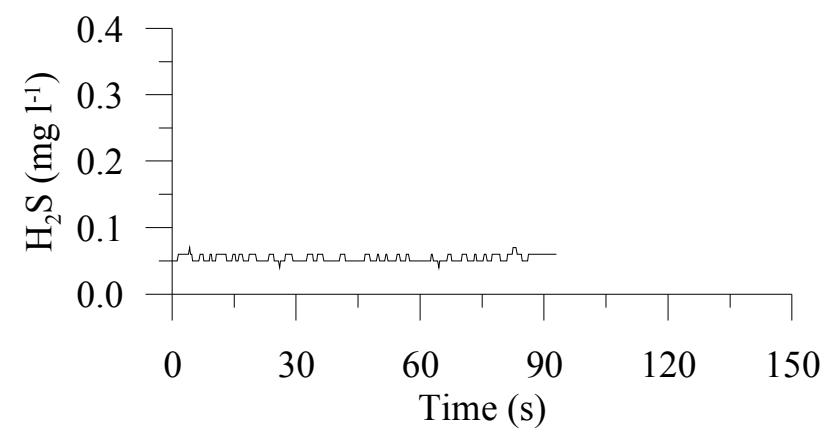

(a)

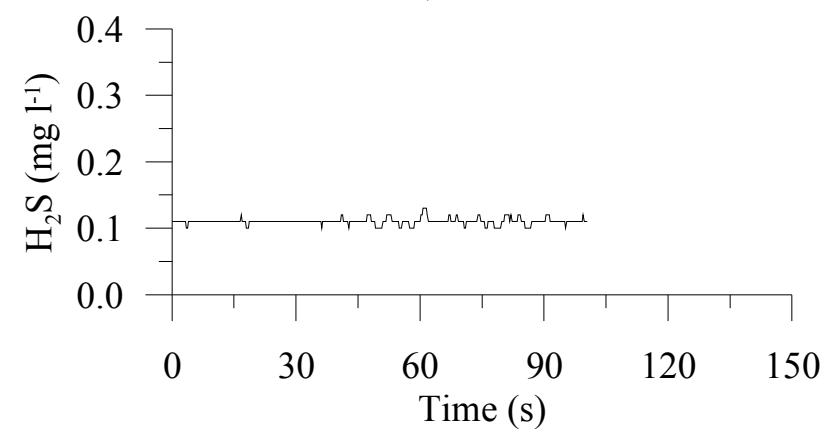

(b)

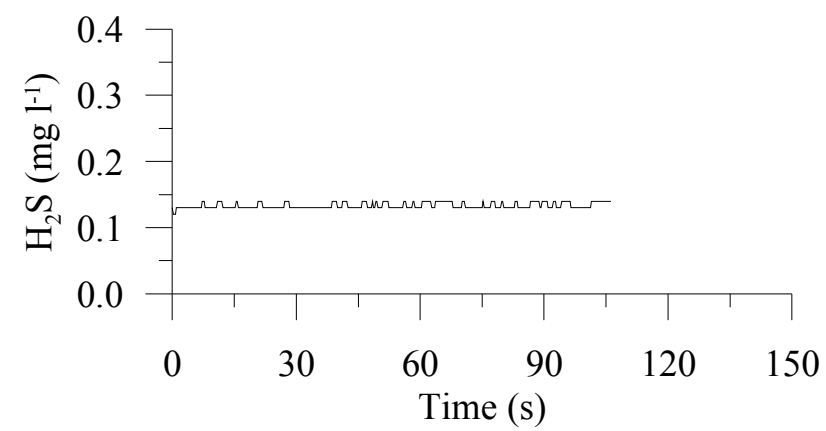

(c)

図 -4 $\mathrm{H}_{2} \mathrm{~S}$ の時間変化（センサータイプ 0.01-3 $\mathrm{mg} \mathrm{l}^{-1}$ ). 9 月 17 日, 地点: D. (a) 水深 : $6 \mathrm{~m},(\mathrm{~b})$ 水深 : $10 \mathrm{~m}$, (c) 水深 : $14 \mathrm{~m}$.

中の標準偏差が示す様に小さかった。その標準偏 差が平均值の $10 \%$ 以上となったのは，センサータ イプ 50 の濃度 $1.0 \mathrm{mg} \mathrm{l}^{-1}$ の回転数 $100 \mathrm{rpm}(21.5 \%), 500$ $\mathrm{rpm}(15.5 \%)$, 濃度 $5.0 \mathrm{mg} \mathrm{l}^{-1}$ の回転数 $100 \mathrm{rpm}(12.8 \%)$ の 3 ケースのみだった.

\section{（2）現場測定データの時間変化}

現場における測定結果の時間変動は，室内実験 と比較すると大きかったが, 時間平均值と比較し て小さいものであった（図-4，5）。ただし，セン サータイプ 0.5-50, 8 月 17 日, 地点 $\mathrm{A}$, 水深 $14 \mathrm{~m}$ の 值（図-5 (a)）は，大きく変動していた。この変動 は, 後述する鉛直分布で示す様に, 水深 $14 \mathrm{~m}$ がちよ うど成層界面に位置していたためであると考えら れる。しかし，その下層の $\mathrm{H}_{2} \mathrm{~S}$ 濃度が $4 \mathrm{mg} \mathrm{l}^{-1}$ 程度 であるにもかかわらず，最大值が $10 \mathrm{mg} \mathrm{l}^{-1}$ 以上の值 となっている理由は不明である。

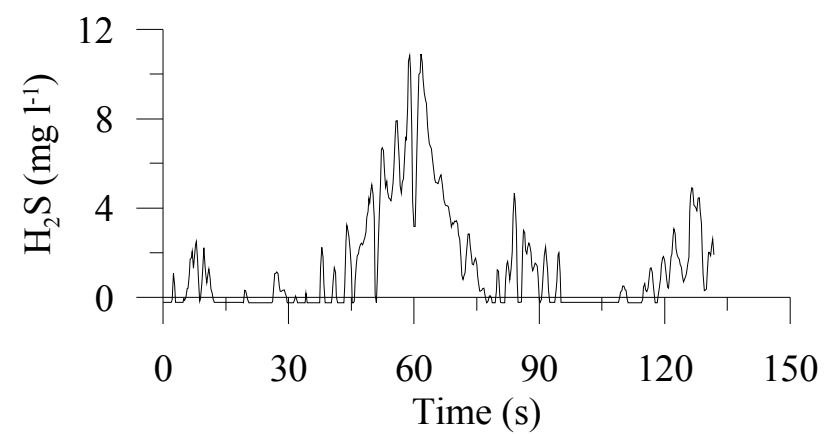

(a)

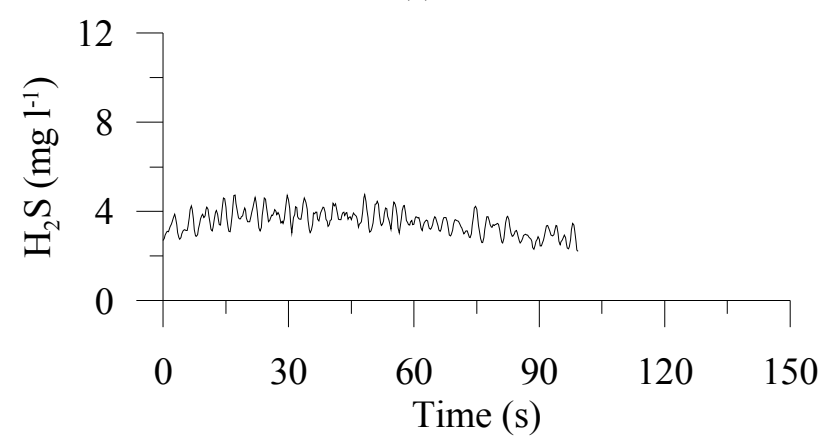

(b)

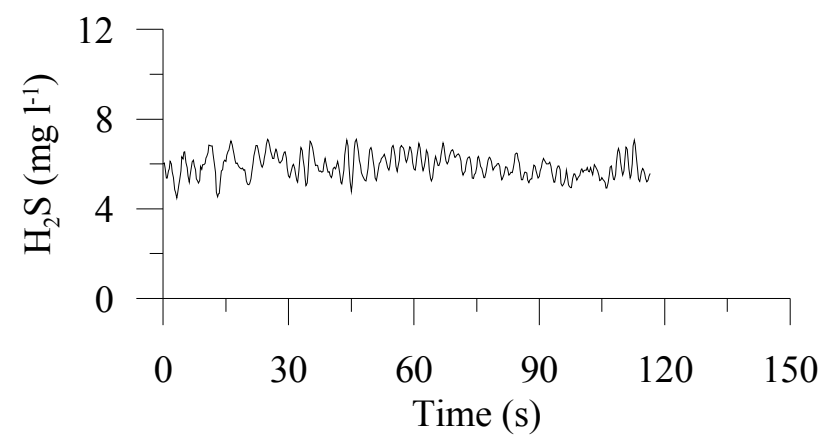

(c)

図-5 $\mathrm{H}_{2} \mathrm{~S}$ の時間変化（センサータイプ 0.5-50 $\mathrm{mg} \mathrm{l}^{-1}$ ).8 月 17 日, 地点 : A. (a) 水深 : $14 \mathrm{~m},(\mathrm{~b})$ 水深 : $22 \mathrm{~m}$, (c) 水深 : $25 \mathrm{~m}$.

\section{（3）浚渫窪地 A における鉛直分布}

$\mathrm{H}_{2} \mathrm{~S}$ 濃度は 3 回の調査共に検出された（図 -6).8 月 17 日と 8 月 27 日には大きな差は無かつたが, 9 月 27 日の值は, それらと比べて大きく, 最深部で最 大值約 $17 \mathrm{mg} \mathrm{l}^{-1}$ に達していた。硫化物濃度に換算す ると, 約 $40 \mathrm{mg} \mathrm{l}^{-1}$ に相当し, この值は市岡ら ${ }^{4)}$ が 2007 年に実施した採水による分析值と一致していた。

周辺の平場の水深は約 $10 \mathrm{~m}$ であるが, 躍層は 8 月 17 日には水深約 $14 \mathrm{~m}, 8$ 月 27 日には水深約 $10 \mathrm{~m}$ に 形成されていた。9 17 日には明確な躍層は無かっ た. DO 濃度は水深 $10 \mathrm{~m}$ 以深で 0 となり, ORP は水 深 $10 \mathrm{~m}$ 以深でマイナスとなっていたが, 顕著な硫 化物が検出されたのは水深 $14 \mathrm{~m}$ 以深だった.

水深 $14 \mathrm{~m}$ 以深においては, 硫化物濃度がに伴い 増大する傾向が測定された。 8 月 27 日のデータの標 準偏差は他の 2 回の調査と比較して大きいが，水深 に伴う増大傾向は, 標準偏差を考慮しても有意な 傾向だった。 


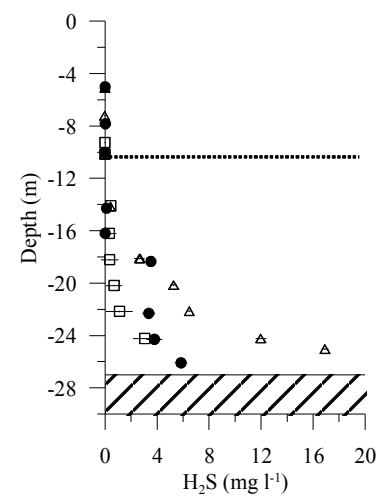

(a)

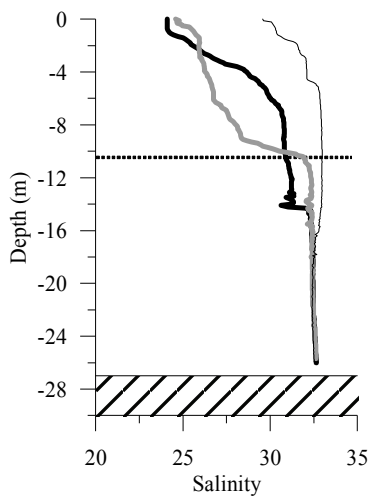

(e)

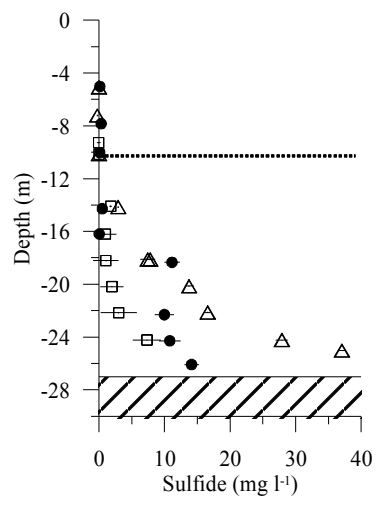

(b)

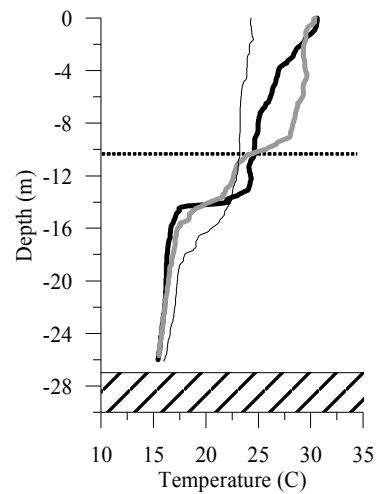

(f)

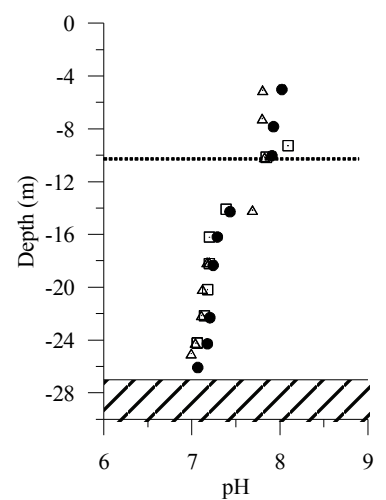

(c)

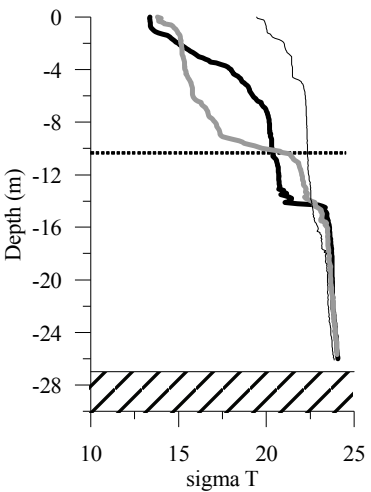

(g)

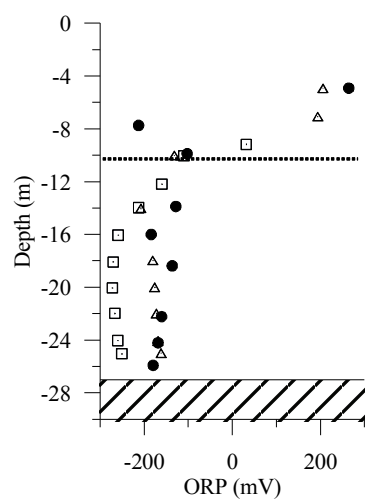

(d)

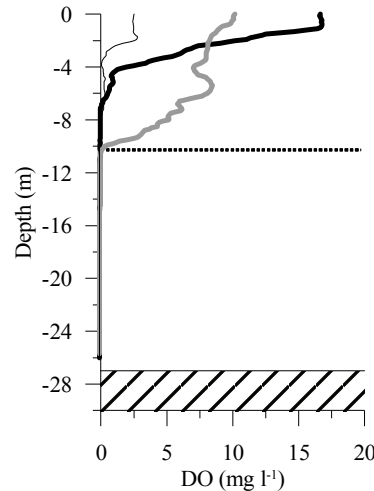

(h)

図-6 浚渫窪地 $\mathrm{A}$ における各指標の鉛直分布. 0 : 8 月 17 日, $\square: 8$ 月 27 日, $\triangle: 9$ 月 17 日. 黒太線 $: 8$ 月 17 日, グ レ一太線 : 8月 27 日, 黒細線 : 9 月 17 日. (a) $\mathrm{H}_{2} \mathrm{~S}$ 濃度, (b) 硫化物濃度, (c) pH, (d) ORP, (e) 塩分, (f) 水温, (g) シグ マ T, (h) 溶存酸素濃度. 水深 $10 \mathrm{~m}$ 付近の破線は浚渫窪地の上面水深. (a)から (d) における各プロットは時間平均 值, バーは標準偏差を示す。

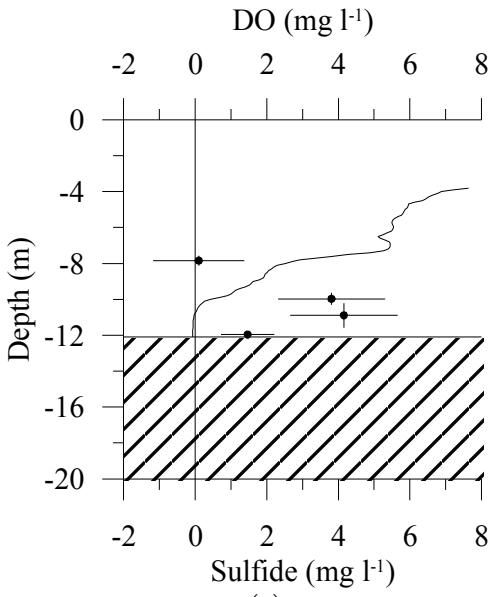

(a)

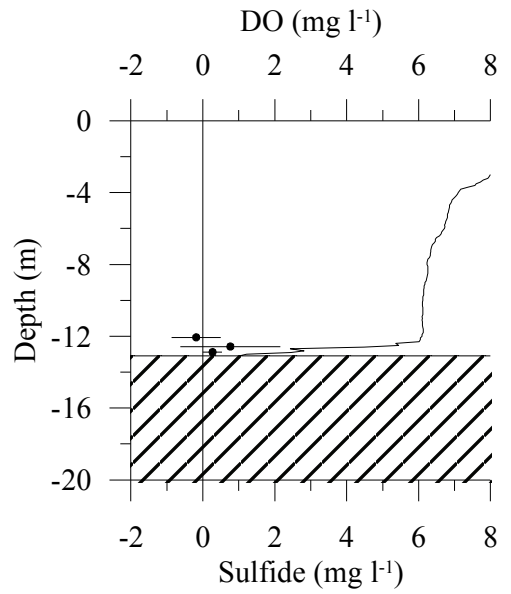

(b)

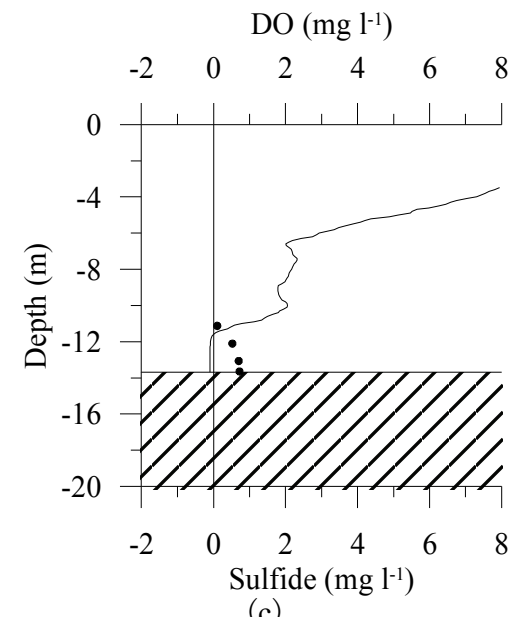

(c)

図-7 地点 Cにおける硫化物濃度

と溶存酸素濃度（実線）の鉛直分布. (a) 8 月 17 日，(b) 8 月 27 日，(c) 9 月 17 日.

\section{（4）平場における鉛直分布}

湾奥の平場である地点 $\mathrm{C}$ においても，底層で硫 化物が検出された（図-7）。その層厚は，無酸素層 の層厚に依存し，8月 17 日および 9 月 17 日におい ては $2 \mathrm{~m}$ 程だった。 8 月 27 日においては, 無酸素層 は底層 $1 \mathrm{~m}$ 程であり，硫化物が検出された層も底面 $1 \mathrm{~m}$ だった。

その硫化物濃度は，8月 17 日には $4 \mathrm{mg} \mathrm{l}^{-1}$ 程度の 比較的高濃度の值だったが，8月 27 日および 9 月 17
日には $1 \mathrm{mg} \mathrm{l}^{-1}$ 以下の低濃度の值だった。

\section{（5）東京港内における鉛直分布}

東京湾内の地点 $\mathrm{F}$ においては，8月 17 日には無酸 素層が底層 $4 \mathrm{~m}$ に形成され，その無酸素層で硫化物 が検出された（図-8). 硫化物濃度は低層ほじ高く, 底面付近では約 $4 \mathrm{mg} \mathrm{l}^{-1}$ の比較的高濃度の值だった。 8 月 27 日には, 無酸素層は底層 $2 \mathrm{~m}$ に形成され，そ の無酸素層で硫化物が検出された。硫化物濃度は 約 $4 \mathrm{mg} \mathrm{l}^{-1}$ の比較的高濃度だった.9月 17 日には, 無 


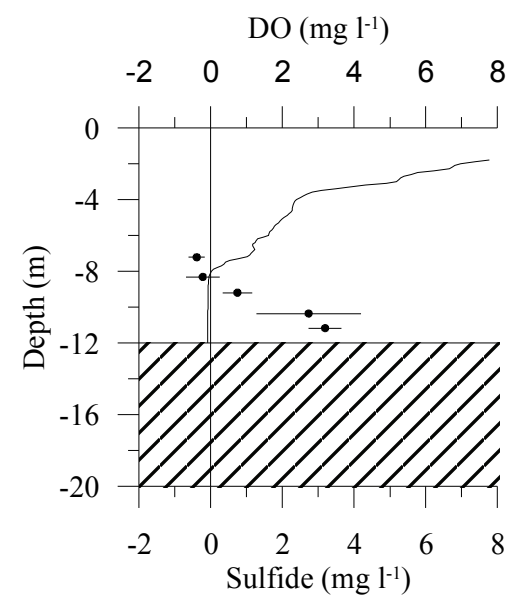

(a)

図-8 地点 $\mathrm{F}$ における硫化物濃度 $\mathrm{DO}\left(\mathrm{mg} \mathrm{l}^{-1}\right)$

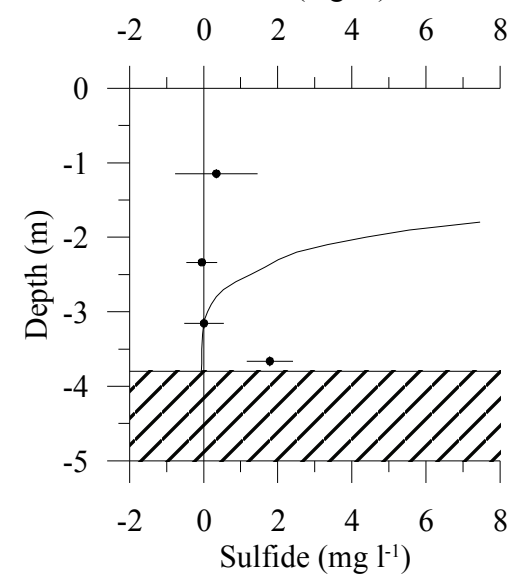

(a)

図-9 地点 $\mathrm{G}$ における硫化物濃度

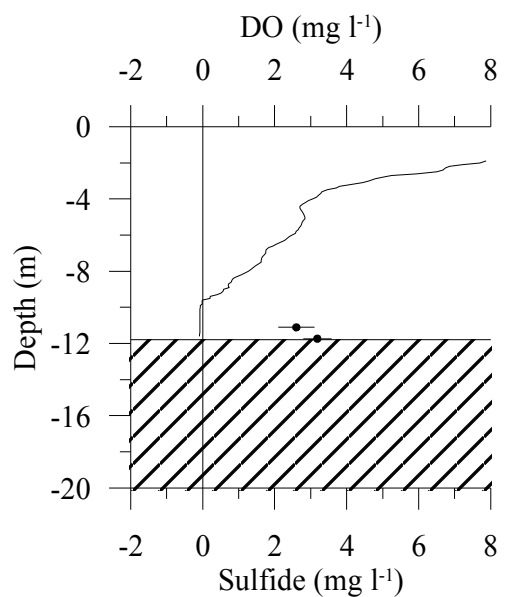

(b)

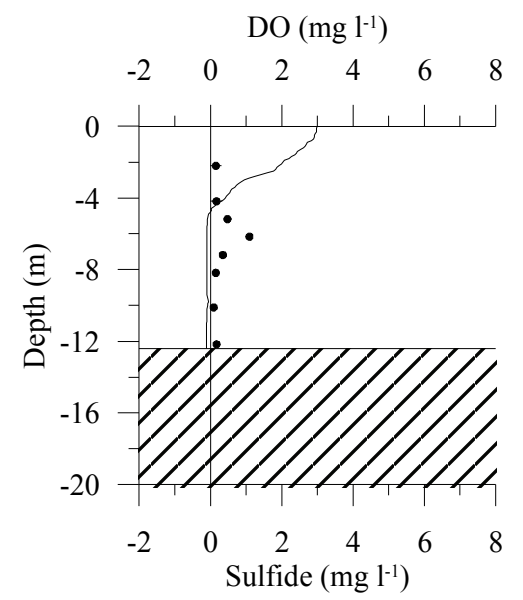

(c)

と溶存酸素濃度（実線）の鉛直分布. (a) 8 月 17 日, (b) 8 月 27 日, (c) 9 月 17 日. DO $\left(\mathrm{mg} \mathrm{l}^{-1}\right)$

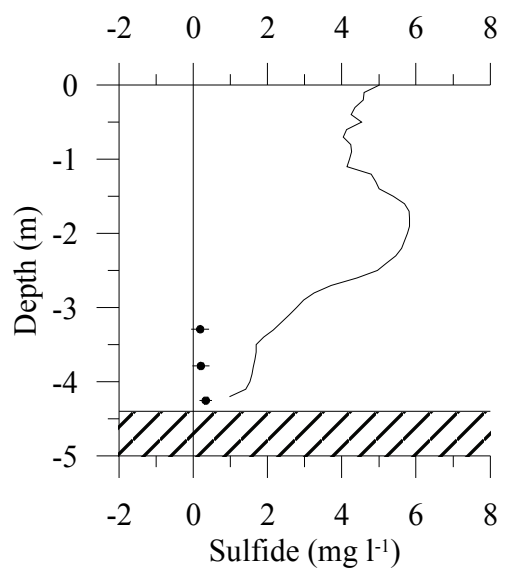

(b)

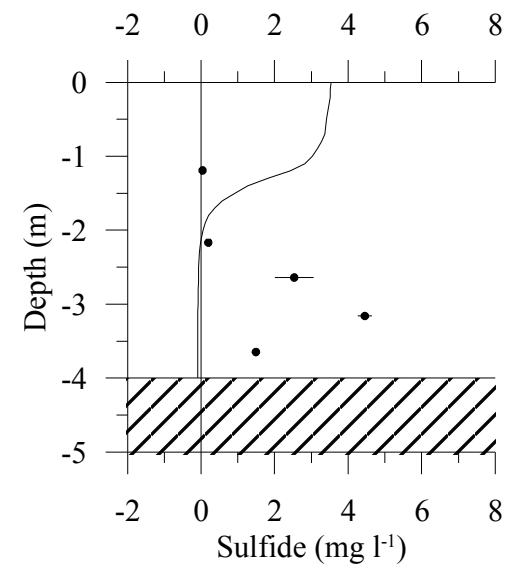

(c)

と溶存酸素濃度（実線）の鉛直分布. (a) 8 月 17 日，(b) 8 月 27 日，(c) 9 月 17 日.

酸素層は水深 $4 \mathrm{~m}$ 以深に形成され, 硫化物は底層で はなくその無酸素層の上部（水深 4-8 m) に存在し ていた.

水深が $4 \mathrm{~m}$ しかない運河部の地点 $\mathrm{G}$ においても, 硫化物は検出された（図-9).8月 17 日には無酸素 層は底層 $1 \mathrm{~m}$ に形成され, 硫化物濃度は底面直上に おいて $2 \mathrm{mg} \mathrm{l}^{-1}$ 程度だった. 8 月 27 日には無酸素層 が形成されていなかったため硫化物は検出されな かったが，9月 17 日には無酸素層が底層 $2 \mathrm{~m}$ に形成 され, $4 \mathrm{mg} \mathrm{l}^{-1}$ 程度の比較的高濃度の硫化物が水深 $3 \mathrm{~m}$ 層にピークを持つ分布で存在していた.

\section{（6）分析値との比較}

本定器で測定された值と分析值を比較した（図 10). 図中の最小二乗法で求めた直線は, 水塊中に $\mathrm{H}_{2} \mathrm{~S}$ が存在しない場合はセンサー值は 0 を取るよう に各調查前に調整しているので，原点を通る様に

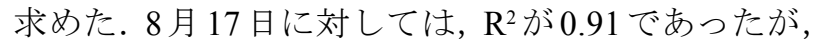
センサー值が低い 1 以下のところで大きな差異が

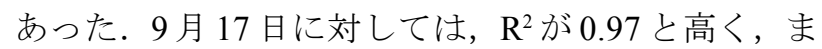
た 0 から 20 のレンジに対して比較的良く一致して いた。 ただ，それでもセンサー值と分析值は倍程
度異なっていた。

傾きに関しては，8月 17 日に対しては3.97だった のに対して，9月 17 日に対しては2.22だった. 両者 をまとめたデータに関しては, $\mathrm{R}^{2}$ は 0.94 だった。

\section{4. 考察およびまとめ}

現場におけるセンサー值と分析值には倍程度の 差があり, 現場における本測器の絶対值の信頼度 は現段階では低いと言わざるを得ない（図-10）。 しかし, 図-3 が示したように, 本センサーは実験 室内では非常に良く一致しており，この誤差は， 現場特有の何かが影響していると考えられる. 当 初考えられたのは, センサー周りの水塊の擾乱の 影響および現場海域に溶存している何らかの物質 の影響だったが，現場底層水を用いた擾乱実験の 結果（図-3）が示寸様に, 両者は顕著な誤差要因 とは考え難い。

各調查地点における硫化物濃度の鉛直分布の形 状は, 無秩序にバラついておらず, 系統的に分布 していることから推察すると, センサー值は相対 


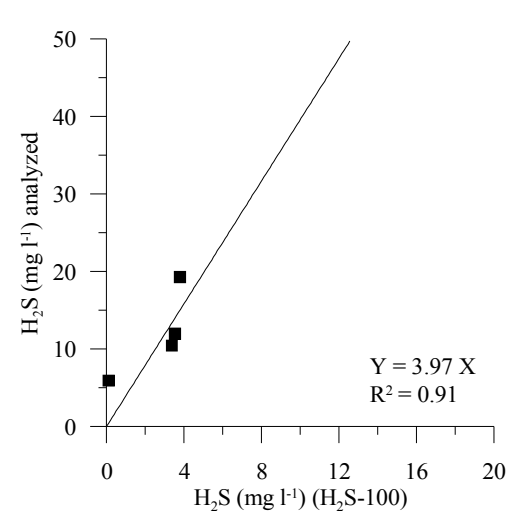

(a)

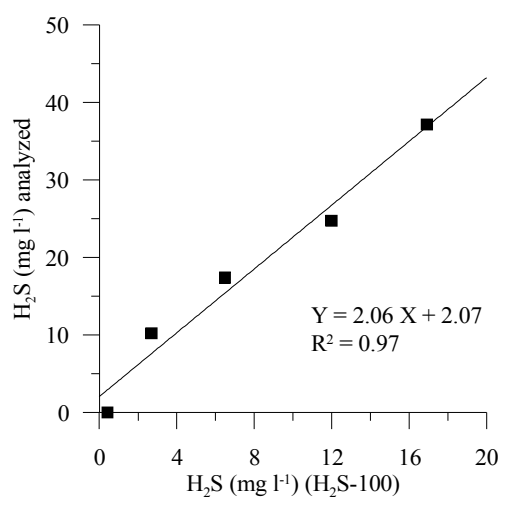

(b)

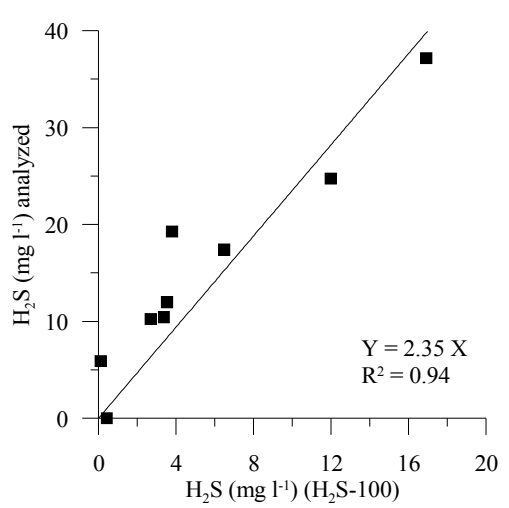

(c)

図-10 $\mathrm{H}_{2} \mathrm{~S}$ 濃度に対するセンサー值と分析の関係. (a) 8 月 17 日, (b) 9 月 17 日, (c) 8 月 17 日 \& 9 月 17 日.

的には妥当な值を示していると考えられる。その ことは，分析值とセンサー值の相関が高いことか らも支持される.

それにもかかわらず両者の絶対值が一致しない ことを考えると, 分析值の結果を疑う必要性もあ る.まず最初に疑われるのは, 採水直後から分析 までの試料の保管方法等である。しかし，保管方 法に不備があった場合，硫化物は揮発・酸化する 傾向があるので，本来の值よりも小さい值になる と考えられるが, 今回の結果では, 分析值の方が 大きな值を示しており, 保管過程に大きな不備が あったことが主要因であるとは考え難い。

また, 調査日によって分析值とセンサー值の比 率が異なることから，調査日間におけるセンサー の劣化等も考えられるが，両日共に新品のセン サーを使用したので，この可能性はないだろう。

分析試料保管および分析過程をもう一度精査す ることを含め，本センサーの誤差要因に関して引 き続き検討したい.

上述の様に, 現段階において本センサー絶対值 には問題があるものの，今回のデータを用いて定 性的な関係を議論することは可能であると考える.

例えば，東京湾湾奥の平場において，濃度は浚 渫窪地内の濃度と比較すると $1 / 10$ 以下だったが, 層厚が $2 \mathrm{~m}$ 程度の硫化物が底層に存在することが 示された (図-7)。この様な硫化物の底層付近の鉛 直分布測定を空間的に多地点で実施すれば，硫化 物層の空間的な分布範囲の特定が可能になる。ま た, 絶対值の信頼度が高まれば, 湾内の硫化物量 の量の評価も可能になる。これらの情報は, 発生 するかもしれない青潮の範囲および規模を予め推 測するリスク管理の点で極めて重要な情報となり 得るだろう。

一方，青潮が殆ど発生しない東京港内および芝 浦運河内においても比較的高濃度の硫化物が存在 し，青潮のポテンシャルはあることが示された (図 -8，9）。東京港内および芝浦運河内では，これ
まで青潮は殆ど発生していないが，これは河川か らの淡水流入によって形成される強い成層によっ て, 底層水の湧昇が抑えられているためと考えら れる. 何らかの事業（エアレーション等の水質改 善策も含む）によって, その成層構造を局所的で も変化させる可能性がある場合には，青潮発生の 危険性を留意しておくべきである.

芝浦運河内では，青潮は発生していないにして も, 水深 $3 \mathrm{~m}$ 当たりでも比較的高い硫化物濃度が存 在することは見逃せない。芝浦運河内では水深 $3 \mathrm{~m}$ 以深には貧酸素水塊が発生することは指摘されて いたが5), 硫化物があるか否かの差は生物の生息 条件としては大きな違いである。

沿岸域の自然再生で今後益々重要視されるであ ろう運河域の様な水際において, 例え青潮が発生 しない場所であっても, 生物生息場の選定および 創造する際には, 硫化物の存在の可能性を念頭に おく必要があるだろう。

\section{参考文献}

1）日向野純也：貧酸素・硫化水素・浮泥等の環境要因が アサリに及ぼす影響, 水産総合研究センター研究報告, 別冊第 3 号, pp.27-33, 2005.

2) AMT, Amperometric H2S micro-sensor, Determination of H2S and toatal sulphide in aqueous solutions, http:// www.amt-gmbh.com/,（2011 年 4 月時点）.

3) American Public Health Association, Standerd methods for theexamination of water \& wastewater, 21 st Edition, 4, pp.179-181, 2005.

4）市岡志保, 佐々木淳, 吉岡侑矢, 松坂省一, 有路隆一, 諸星一信 : 東京湾奥部の浚渫窪地における硫化物量の 簡易推定手法の提案, 海洋開発論文集, Vol.24, pp.669674, 2008.

5）岡田知也, 古川恵太, 運河部の貧酸素水塊に及ぼす内 湾部の貧酸素水塊の影響, 海洋開発論文集, Vol.26, pp.663-668, 2010. 